Commission on Macromolecules of the International Union of Pure and Applied Chemistry

Representative:

C. W. Bunn, I.C.I. Ltd, Plastics Division, Black Fan Road, Welwyn Garden City, Herts., Eng. land

\section{Abstracting Board of the International Council of} Scientific Unions

Observers:

W. B. Pearson, Division of Pure Physics, National Research Council, Ottawa 2, Ontario, Canada A. J. C. Wilson, Department of Physics, University College, Cathays Park, Cardiff, Wales

\section{(21) Votes of thanks}

At the ceremonial closing session of the Assembly, the following votes of thanks were passed by acclamation:

(a) To UNESCO for financial support which had contributed greatly to the success of the meetings held in Leningrad and in Stockholm in 1959, and of the current meetings in Cambridge.

(b) To the Academy of Sciences of the U.S.S.R. for inviting the Union to participate in the Symposia held in Leningrad in May 1959, and for all arrangements made by the Academy on that occasion; to the organizers of these Symposia for their work in respect of the scientific programme as well as for the wonderful programme of social events; and to the Russian hosts for the many facilities which had made the stay in Leningrad so pleasant and interesting, and for all help and hospitality received.

(c) To Karolinska Institutet and to the Swedish hosts, in particular A. Engström, for the hospitality received in Stockholm in June 1959, and for their assistance in the organization of the three very successful Conferences held there by the Commission on Crystallographic Apparatus.

(d) To the Royal Society and the University of Cambridge for inviting the Fifth General Assembly and International Congress to Cambridge, and for their invaluable help in the organization of these meetings; to N.F. Mott for making available the facilities of the Cavendish Laboratory; to the Congress Executive consisting of W. H. Taylor (Chairman), E. G. Cox, D. M. Hodgkin, Dame Kathleen Lonsdale and A. J. C. Wilson (members), and to the Congress Finance Committee consisting of Sir Lawronce Bragg (Chairman), D. A. Oliver and H. P. Rooksby (members), for all the work that they had devoted to the organizing; to the fifty British organizations and institutions which had given generous financial support; and in particular to W. H. Taylor and his team of co-workers, R. C. Evans, P. Gay, N. F. M. Henry, (Mrs) M. A. Hirsch, Christine H. Kelsey and many others, for the superb organization of all arrangements for the meetings, which had almost double the attendance of the previous Assembly and Congress, and which had demanded so much effort and time in arranging the innumerable details which are necessary for the smooth operation of a Congress of this size.

(e) To the Programme Committee consisting of W. H. Taylor (Chairman), R. E. Rundle, E. H. Wiebenga and G. S. Zhdanov (members), to the organizers of the two Symposia, G. E. Bacon and P. B. Hirsch, and to all others who had assisted in arranging the scientific programme of the Congress and Symposia, for their contribution to the organization of the Cambridge meetings.

( $f$ ) To the Executive. Committee, in particular to the President, J. Wyart, to the Officers who were retiring, A. Guinier, C. H. MacGillavry, A. J. C. Wilson and R.W. G. Wyckoff, and to the General Secretary, D. W. Smits, for the work they had done for the Union during the period since the Fourth General Assembly.

\section{Fifth International Congress}

\section{(1) Scientific Programme}

The scientific programme of the Congress consisted of:

(a) A Congress Discourse on 'The growth in the power of X-ray analysis' given by Srr LAwrence BragG on 17 August.

(b) The following five General Lectures presented by invited speakers:

'The crystal chemistry of silicates, Chapter 2' by N. V. BeLov;

'Theory of metals', four statements given in succession by N. F. Mott, J. C. Slater, R. E. Rundle and D. P. Shommaker [the latter two speakers substituted for L. Pauling whose original paper is included in the Abstracts];

'Magnetic alignment' by J.H. VAN V'LECK;

'Structure of crystalline proteins' by M. F. Perutz; and

'Theory and practice of direct methods of structure analysis' by B. K. VAINSHTEIN and co-authors.

(c) More than 400 contributed papers arranged in nineteen groups of topics, and presented during the five days of the Congress at four to eight simultaneous morning and afternoon sessions. A novelty at the Congress was the use of a Rapporteur System in order to reduce the total number of sessions. Five topics had been selected for treatment under this system: (i) Minerals (including clay minerals); (ii) Metals and alloys; (iii) Inorganic structures; (iv) Organic structures; and (v) Proteins and related compounds. All papers offered in these groups, together amounting to nearly 200, were included in critical reviews of groups of related papers, which were given by eighteen invited Rapporteurs. At the session concerned the authors of the papers included in the review of the Rapporteur had to be present to take part in the discussion which followed.

Diverging opinions about the value and usefulness of the Rapporteur system were expressed during the Congress, varying from strongly in favour to very much opposed. As was to be expected, some authors would have preferred to read their own papers, and some Rapporteurs succeeded better with their reviews than others. The condensation achieved with related papers, and the time for discussion gained thereby, were, however, considered features encouraging a further try-out of the Rapporteur System.

Abstracts of the papers presented at the Congress, including those included in the Rapporteurs' reviews and those which were read in title only, had been distributed in advance, and they are reprinted elsewhere in this issue.

\section{(2) Exhibitions}

(a) An exhibition of commercial apparatus had been organized by E.J.W. Whittaker and the Equipment 
Sub-Committee of the X-ray Analysis Group of the Institute of Physics. In this exhibition 36 firms participated, and descriptions of their exhibits were included in an Exhibition Handbook which was distributed to all members of the Congress.

(b) There was also organized an exhibition of apparatus, diagrams, etc., offered by individual members of the Congress to illustrate techniques or procedures which they had developed, or results which they had obtained.

(c) The Commissions on Crystallographic Data and Crystallographic Teaching had jointly arranged for an exhibition of books on crystallographic and closely related subjects, of tables and charts, and of various aids to teaching. A catalogue of the books on display, classified by subjects, had been prepared by the secretaries of these Commissions, and was available in the exhibition room.

(d) An unusual exhibition was a collection prints and of drawings by M. C. Escher, in whose work crystallographers can see ideas familiar to them interpreted by an artist. Mention should be made here of a delightful lecture on 'Antisymmetrical arrangements in the plane, and regular three-dimensional bodies as sources of inspiration to an artist', given by M. C. Escher at the session on symmetry.

\section{(3) Social arrangements}

(a) In view of the limited hotel accomodation in Cambridge, the Congress Executive had arranged for most members of the Congress to have rooms in Colleges, and a debt of gratitude is owed to the following ten Colleges and their staff for the great hospitality received: Christ's, Clare, Downing, Emmanuel, Girton, Gonville and Caius, Pembroke, St Catharine's, Sidney Sussex and Trinity.

(b) For the members of the Congress the following programme of social events was organized. On 16 August a reception was given in the Old Schools by the University of Cambridge. The Mayor and the Corporation of the City of Cambridge received the Congress at a reception in the Guildhall on 17 August before lunch. For the evening of the same day a Wine and Cheese Party had been arranged by the Directors of Research and Control Instruments Ltd on behalf of the Philips Companies throughout the world. On 18 and 19 August special Congress Dinners were offered by the Congress Executive in the following Colleges: Downing, King's, St Catharine's, St John's and Trinity; and on 18 August also in the University Arms Hotel. An Orchestral Concert by the Philomusica Orchestra of London in King's College
Chapel on Saturday night 20 August closed the series of social events.

(c) Already in June a brochure had been sent to all persons who had registered for the Congress, with full details of a list of selected visits and excursions, four of short, six of medium and nine of long duration, to places of interest in Cambridge and the surrounding districts. These visits and excursions took place during the afternoons of 17 and 21 August, and no charge was made for participation in any of these and the other events.

(d) A further programme of social events had been arranged for the accompanying members, and warm thanks are due to the Ladies' Committee consisting of Mrs A. Taylor (Chairman), Mrs Cochran, Mrs Gay, Mrs Hirsch and Mrs Nockolds (members) for organizing this programme which made the stay in Cambridge of the accompanying members still more pleasant and interesting. This programme included a lecture by G. F. Hickson on 'The City and University of Cambridge', and a Garden Party at the Master's Lodge of Gonville and Caius College, by invitation of Mrs Mott, on 15 August; a visit to Girton College on 18 August, where a short talk on the education of women in Cambridge was given; and various visits and excursions on 16, 18, 19 and 20 August.

\section{Symposia}

Following the Congress, two Symposia were held, devoted respectively to 'Thermal motion in crystals and molecules' and 'Lattice defects and the mechanical properties of solids'. The general introductory lectures, given within the Congress period on 20 August, were as follows:

J. C. Slater. The interaction of mechanical and electromagnetic waves in crystals.

N. F. Moтt. Lattice defects and the mechanical properties of solids.

About thirty papers were presented at the first Symposium during four morning and evening sessions on 22 and 23 August, the afternoons being left free for discussions. The number of contributed papers for the second Symposium exceeded ninety; they were read during nine morning, afternoon and evening sessions on 22, 23 and 24 August.

The procedure at the Symposia was practically the same as that at the Congress for those topics which had not been treated under the Rapporteur system; after each paper there was opportunity for informal discussion. Abstracts of the papers presented at the Symposia had also been distributed in advance to the registered members, and are republished elsewhere in this issue.

\section{Statutes and By-Laws of the International Union of Crystallography}

The Statutes and By-Laws were adopted by the Fourth General Assembly, Montreal, July 1957, and amended by the Fifth General Assembly, Cambridge, August 1960.

\section{STATUTES}

\section{Objects of the Union}

1.1. The objects of the Union are (a) to promote international co-operation in crystallography;

(b) to contribute to the advancement of crystallography in all its aspects, including related topics concerning the non-crystalline states;

(c) to facilitate international standardization of methods, of units, of nomenclature and of symbols used in crystallography;

(d) to form a focus for the relations of crystallography to other sciences. 